\title{
Mistä johtuu kasvava ero elintarvikkeiden vähittäismyynti- ja tuottajahintojen välillä?
}

\author{
Timo Kuosmanen \& Jyrki Niemi \\ MTT Taloustutkimus, Luutnantintie 13, 00410 Helsinki \\ timo.kuosmanen@mtt.fi,jyrki.niemi@mtt.fi
}

\section{Tiivistelmä}

Kasvava ero elintarvikkeiden vähittäismyynti- ja tuottajahintojen välillä on havaittu monissa empiirisissä tutkimuksissa sekä Euroopassa että USA:ssa useiden eri elintarviketuotteiden osalta. Tämä ero eli niin sanottu hintamarginaali edustaa kaikkia maataloustuotteisiin lisättäviä keräily-, jalostus-, kuljetus- ja vähittäismyyntikustannuksia. Sitä käytetään yleisesti elintarvikejalostuksen ja kuljetuspalveluiden suorituskyvyn mittarina. Tuottajaryhmät, kuluttajajärjestöt ja maatalouspolitiikan tekijät vetoavat tavallisesti hintamarginaalilukuihin esitellessään näkemyksiään elintarvikeketjun tehokkuudesta.

Tämä tutkimus selvittää hintamarginaalien kasvun mahdollisia syitä ja painotuksia Suomen näkökulmasta. Ilmiölle on löydettävissä kuusi mahdollista selitystä: 1) tuotteiden korkeampi jalostusaste, 2) parempi elintarvikehygienia, 3) erot tuottavuuden kasvussa eri sektoreilla, 4) maatalouspolitiikka, 5) kansainvälisen kaupan vapautuminen, ja 6) epätäydellinen kilpailu. Tässä tutkimuksessa arvioidaan kutakin hypoteesia saatavissa olevan empiirisen todistusaineiston perusteella.

Jalostusasteen nousu yhdessä valmisruokien ja puolivalmisteiden kasvaneen kulutuksen kanssa on yksi selittävä tekijä hintamarginaalien kasvuun. Kun kuluttajat vaativat entistä valmiimpia tai pidemmälle jalostettuja tuotteita, alkutuotannon osuus vähittäishinnasta laskee.

Elintarvikehygienian tiukempien standardien käyttöönotto on omalta osaltaan lisännyt elintarviketeollisuuden ja vähittäismyyntisektorin kustannuksia. Nämä kustannukset nostavat kuluttajahintoja ja laskevat alkutuotannon arvon osuutta.

Viljelijöiden osuus vähittäismyyntihinnoista pienenee myös sen johdosta, että kustannukset ja tuottavuus kehittyvät eri tahtia maataloudessa, elintarvikejalostuksessa ja vähittäismyyntisektoreilla. Maatalouden alati kasvava tuottavuus on tasaisesti vähentänyt maataloustuotteiden reaalihintoja.

Myös maataloustuella on vaikutuksensa hintamarginaaleihin. Tuen seurauksena kuluttajahintojen tuottajaosuus saattaa laskea, vaikka tuottajan osuus elintarvikkeiden yhteiskunnallisista kokonaiskustannuksista pysyisi vakaana.

Maataloustuotteiden ja elintarvikkeiden tukkukaupan markkinoiden avautuminen kansainväliselle kaupalle ja vähittäiskaupan pysyminen paikallisesti rajoittuneena on myös vaikuttanut hintamarginaalien kehitykseen. Vähittäiskaupan neuvotteluasema on vahvistunut elintarvikeketjussa suhteessa kotimaiseen maatalouteen ja elintarviketeollisuuteen, kun kotimaiset tavarantoimittajat kilpailevat ulkomaisten kanssa hyllytilasta vähittäismyyntimarkkinoilla.

Markkinavoimien väärinkäytöllä saattaa myös olla merkitystä hintamarginaalien kasvuun. Suuret vähittäismyyntiketjut ovat hankkineet ostovoimaa fuusioiden ja yrityshankintojen avulla sekä hyödyntämällä kansainvälisiä osto-organisaatioita ja kaupan omia tuotemerkkejä, mikä on saattanut vaikuttaa johtavan markkina-aseman hyväksikäyttöön. Ostajan voima ei ole rajoittunut elintarvikkeiden vähittäismyyntiin, myös elintarvikkeita jalostava teollisuus voi käyttää ostajan voimakasta asemaa hyväkseen.

Asiasanat: elintarvikkeet, vähittäishinnat, hintamarginaali. 


\section{Johdanto}

Kasvava ero elintarvikkeiden vähittäismyynti- ja tuottajahintojen välillä on havaittu useissa empiirisissä tutkimuksissa sekä Euroopassa että USA:ssa useissa eri tuoteryhmissä (Digby 1989, Kinsey ja Senauer 1996, Løyland et al. 2001, Reed et al. 2002, Kjuus 2004, Niemi ja Jansik 2005). Tämä ero eli 'hintamarginaali' edustaa kaikkia maataloustuotteisiin lisättäviä keräily-, jalostus-, kuljetus- ja vähittäismyyntikustannuksia. Sitä käytetään yleisesti elintarvikejalostuksen ja kuljetuspalveluiden suorituskyvyn mittarina. Tuottajaryhmät, kuluttajajärjestöt ja maatalouspolitiikan tekijät vetoavat usein hintamarginaalilukuihin esitellessään näkemyksiään elintarvikeketjun tehokkuudesta. Aiheesta on ilmestynyt myös runsaasti kirjallisuutta (kts. Wohlgenant 2001 viitteineen).

Vaikka monet tutkimukset tulkitsevat kasvavan eron elintarvikkeiden vähittäismyynti- ja tuottajahintojen välillä osoituksena elintarvikemarkkinoilla vallitsevasta epätäydellisestä kilpailusta, muitakin mahdollisia selityksiä on huomioitava. Ilmiölle on löydettävissä ainakin kuusi mahdollista selitystä: 1) tuotteiden korkeampi jalostusaste, 2) parempi elintarvikehygienia, 3) erot tuottavuuden kasvussa eri sektoreilla, 4) maatalouspoliittiset uudistukset, 5) kansainvälisen kaupan vapautuminen, ja 6) epätäydellinen kilpailu.

On tärkeää, että kaikki mahdolliset selitykset tutkitaan yhdessä, jotta ymmärretään paremmin tarjontaketjun dynamiikkaa sekä poliittisten interventioiden tarvetta ja laatua. Tässä tutkimuksessa arvioidaan kutakin hypoteesia Suomesta saatavissa olevan empiirisen aineiston perusteella. Myös eräitä uusia tapoja näiden hypoteesien testaamiseksi ehdotetaan.

\section{Hintamarginaalien kasvun mahdollisia syitä}

\section{Valmisruoat ja puolivalmisteet}

Elintarvikkeiden lisääntynyt jalostusaste on yksi selitys kasvavalle erolle vähittäismyynti- ja tuottajahintojen välillä. Valmisruokien ja puolivalmisteiden kasvava valikoima on muuttanut elintarvikkeiden kulutustottumuksia. Yhä suurempi osuus aiemmin kotitalouksien suorittamasta ruoanvalmistuksesta tehdään nykyään elintarvikkeiden jalostuksessa ja kaupassa. Elintarvikkeiden jalostus- ja vähittäismyyntiliikkeet eivät ole enää ainoastaan maatilojen alkutuotteiden markkinointivälittäjiä, vaan ne myös antavat tuotteille huomattavaa lisäarvoa. Jalostusasteen nousu kasvattaa elintarvikkeiden kulutusmenoja ja tekee samalla tuottajahintamarginaalien laskemisesta haastavampaa. Valmisruoat koostuvat suurista määristä eri aineksia, joita käytetään suhteellisen pieninä erinä. Tällöin tuottajaosuuden arvioimisesta tulee entistä vaikeampi tehtävä.

Kun ottaa huomioon käytännön vaikeudet arvioitaessa pitkälle jalostettujen elintarvikkeiden kuten pakastepitsojen tuottajaosuutta, esitetyt hintamarginaalit on tyypillisesti arvioitu standardoiduille homogeenisille tuotteille, joilla on suhteellisen matala jalostusaste - kuten nestemäinen maito, vehnäjauho tai jauheliha. Hintamarginaalit ovat kasvaneet huomattavasti jopa näissä matalan jalostusasteen tuotteissa, jotka ovat pysyneet koostumukseltaan lähes samanlaisina vuosikymmenien ajan.

Jalostuksen korkeammalla asteella ei siis välttämättä ole mitään tekemistä kasvavien hintamarginaalien kanssa. Silti kaksi vastakkaista huomautusta on esitettävä. Ensinnäkin jalostettujen elintarvikkeiden lisääntynyt markkinaosuus on saattanut laskea hintamarginaalianalyyseihin valittujen matalan jalostusasteen tuotteiden valmistusmääriä. Mikäli elintarvikkeiden jalostusyritykset omaavat mittakaavaetuja, tarkasteltavien tuotteiden vähentyneet tuotantomäärät johtavat näiden tuotteiden jalostuskustannusten nousuun ja sen myötä kuluttajahintojen kohoamiseen.

Toiseksi, elintarvikkeita jalostavat yritykset ovat saattaneet havaita, että on kannattavaa ristiin subventoida korkeasti jalostettuja tuotteita matalasti jalostettujen tuotteiden kustannuksella. Pitämällä valmisruoka- ja puolivalmistetuotteiden marginaalit alhaalla ja matalasti jalostettujen tuotteiden marginaalit korkealla, yritykset pystyvät muokkaamaan kuluttajien käytöstä haluamallaan tavalla. Tuotteiden erilainen tukeminen ei välttämättä merkitse hyvinvointitappiota kuluttajille; useita tuotteita valmistavat yritykset voivat ristiin subventoida eri tuotteitaan kilpailullisessa markkinoiden tasapainotilanteessa. 


\section{Elintarvikehygienia}

Elintarvikejalostuksen ja vähittäiskaupan lisäarvo saattaa nousta, vaikka elintarvikkeiden koostumuksessa ei olisi tapahtunutkaan huomattavaa muutosta. Viime vuosikymmenten aikana elintarvikehygienian standardeihin on kiinnitetty yhä enemmän huomiota, mikä on saanut elintarvikejalostus- ja vähittäismyyntisektorit panostamaan enemmän elintarvikeketjun laatu- ja turvallisuustekijöihin - joko vapaaehtoisesti tai valtiovallan sääntelyn kautta. Jalostusteollisuudessa laatua valvotaan yhä enenevässä määrin itsenäisesti kontrolloitujen ohjelmien avulla, jotka takaavat korkealaatuiset tuotantoprosessit ketjun joka vaiheessa. Hygienian korkeammat standardit aiheuttavat yrityksille luonnollisesti lisäkustannuksia, jotka siirretään kuluttajahintoihin.

Tiukemmat standardit näkyvät erityisesti meijeri- ja lihatuotteissa, joilla kylmävarastointi ja kuljetus aiheuttavat huomattavia kustannuksia; kun taas viljatuotteiden (kuten vehnäjauhon) kohdalla varastointi- ja kuljetuskustannukset eivät ole läheskään yhtä merkittäviä.

Tiukemmilla standardeilla saattaa olla merkitystä hintamarginaaleihin pitkällä tähtäimellä, etenkin siinä tapauksessa, kun tarvitaan poikkeuksellisia sääntelytoimenpiteitä eläintautien nujertamiseksi (esim. hullun lehmän taudin puhkeaminen Iso-Britanniassa). Lyhyellä aikavälillä standardien muutokset eivät tosin selitä hintamarginaaleissa tapahtunutta kasvua.

\section{Kustannukset ja tuottavuus}

Vähittäishinnan tuottajaosuus saattaa muuttua myös sen vuoksi, että maatalouden tuottavuus kasvaa merkittävästi elintarviketeollisuuden ja vähittäiskaupan tuottavuuskasvua nopeammin. Teollistuneissa maissa havaittu tuottajaosuuden pitkän aikavälin laskeva trendi näyttäisi tukevan tätä selitystä. Maatalous onkin kokenut poikkeuksellisen voimakkaan rakenteellisen muutoksen viimeisten vuosikymmenien aikana. Sille on ollut ominaista tilaluvun ja työvoiman väheneminen, tuotannon koneellistuminen ja tehostuminen, alueellinen ja tilakohtainen erikoistuminen sekä tilakohtaisesta omavaraisuudesta luopuminen.

Kattava ja runsaasti huomiota herättäneessä O'Mahoneyn ja van Arkin (2003) tuottavuustutkimuksessa on verrattu tuottavuuden kehitystä Euroopassa ja USA:ssa eri toimialoilla. Tulokset osoittavat, että kokonaistuottavuuden (TFP) kasvu on ollut merkittävästi nopeampaa maataloudessa kuin elintarviketeollisuudessa tai vähittäiskaupassa kaikkina kolmena tarkasteluajanjaksona. Nämä erot tuottavuuskasvussa selittävät ainakin osittain tuottajamarginaalin laskevaa osuutta kuluttajahinnoissa.

Junka (2003) on raportoinut vastaavia TFP-lukuja myös Suomen osalta. Junkan laskelmien mukaan maatalouden suurempi TFP-kasvu ei täysin selitä hintamarginaalien kasvua Suomessa. Jos kuitenkin katsotaan työn tuottavuutta (eli tuotos/työ-suhde), niin maatalouden tuottavuuskasvu on edennyt selvästi nopeammin kuin elintarvikejalostuksessa ja vähittäiskaupassa. Vaikka TFP ottaa monipuolisesti huomioon panosten kokonaiskäytön, niin työn tuottavuuden luvut saattavat olla soveliaampia tässä tarkastelussa kahdesta eri syystä. Ensiksikin, palkat ja muut työkustannukset kattavat yli puolet elintarvikejalostuksen ja vähittäiskaupan kokonaiskustannuksista. Toiseksi, maatalouden pääomapanoksia on tuettu investointitukien ja hehtaariperusteisten tukien avulla, mikä on edesauttanut viljelijöitä kasvattamaan työn tuottavuutta pääoman tuottavuuden kustannuksella: kun työtä on korvattu pääomapanoksilla, työn tuottavuus kasvaa nopeammin kuin TFP.

\section{Maatalouspolitiikka}

Maataloutta säädellään ja tuetaan voimakkaasti sekä Euroopassa että USA:ssa. Viime vuosikymmenen aikana maatalouden tukitoimenpiteiden painotus on muuttunut hintatuesta suoriin tukiin. Esimerkiksi EU:ssa viljan ja naudanlihan interventiohinnat alennettiin lähemmäs maailmanmarkkinahintoja vuosien 1992 ja 1999 CAP-reformien myötä. Hinnan alennukset kompensoitiin suorilla tuilla, minkä seurauksena eläin- ja pinta-alaperusteisten tukien asema on muodostunut keskeiseksi tuotekohtaisissa hintaja markkinajärjestelmissä.

Maatalouspolitiikalla on siten vaikutusta hintamarginaaleihin, etenkin suorien ja epäsuorien tukien kautta. Kun yhä suurempi osa viljelijöiden tuloista koostuu suorista tai epäsuorista tuista, niin tuottajahinnat tai elintarvikkeiden vähittäismyyntihinnat eivät kata tuotannon kokonaiskustannuksia, mikä puolestaan vaikuttaa hintamarginaaleihin. Siten alkutuotannon tukiosuuden kasvaminen yli ajan voi selittää alenevia tuottajamarginaaleja suhteessa elintarviketeollisuuden ja vähittäismyynnin marginaaleihin. 


\section{Kansainvälinen kauppa}

Eri maiden harjoittama kauppapolitiikka vaikuttaa myös voimakkaasti elintarvikemarkkinoihin. Monet maat suojelevat kotimaista elintarviketuotantoaan asettamalla tuontitulleja ja tuontikiintiöitä. Viime vuosikymmenien aikana paineet maatalouskaupan vapauttamiseen ovat kuitenkin kasvaneet. Vuonna 1994 allekirjoitettu Uruguayn neuvottelukierroksen maataloussopimus (URAA= The Uruguay Round Agreement on Agriculture) muutti kansainvälisen maatalouskaupan sääntöjä varsin perusteellisesti. Kaikille Maailman kauppajärjestö WTO:n (World Trade Organization) jäsenmaille asetettiin määrällisiä rajoitteita vientitukien ja tuontitullien soveltamiseen.

Kansainvälisen kaupan vapauttaminen on hyödyttänyt erityisesti vähittäiskauppaa, joka pystyy hankkimaan tuotantopanoksensa erittäin kilpailukykyisiltä kansainvälisiltä markkinoilta ja samaan aikaan se voi toimittaa tavaraa paikallisesti rajoittuneille kuluttajamarkkinoille. Tämän seurauksena eri maiden hintaerot ovat paljon suuremmat vähittäismyyntihinnoissa kuin alkutuotannossa. Kaupan vapauttamisen vaikutukset liitetään usein suoraan elintarviketeollisuuden ja vähittäiskaupan kasvaneeseen ostovoimaan.

\section{Markkinavoimat}

Hallitsevan markkina-aseman hyödyntäminen mainitaan usein selityksenä laskeviin tuottajahintamarginaaleihin. Tämä on selkeästi yksi mahdollinen selitys. Elintarviketeollisuus ja etenkin vähittäiskauppa ovat yhdistyneet fuusioiden, strategisten liittoutumien ja muiden yrityskokoa suurentavien järjestelyjen kautta. Vähittäiskaupasta on tulossa yhä keskittyneempää, mikä johtuu osittain siitä että vähittäismyyjät yhdistävät ostotoimintojaan. Keskittyminen on ollut voimakkaampaa ostajapuolella kuin myyjäpuolella kautta Euroopan (Dobson et al. 2003). Suomessa vähittäiskauppasektorin keskittyminen on ollut erityisen nopeaa. Kaksi johtavaa elintarvikkeiden ja päivittäistavaratuotteiden vähittäismyyntiketjua kasvattivat markkinaosuuttaan 55 prosentista vuonna 1990 lähes 70 prosenttiin vuonna 2005 (Niemi ja Ahlstedt 2006).

Silti markkinavoiman väärinkäytön todistaminen on melko vaikeaa, sillä suuri markkinaosuus ei välttämättä tarkoita suurta markkinavoimaa. Koeteltavien markkinoiden teorian mukaan (esim. Baumol et al., 1982), markkinat, joita kuvastaa vähäinen määrä myyjïä - tai jopa monopoli - voivat ylläpitää kilpailullista hinnoittelua, mikäli markkinoillepääsyn ja sieltä poistumisen esteet ovat matalat. Jos yritys nostaa hintojaan yli marginaalikustannusten ansaitakseen poikkeuksellisia voittoja ilman markkinoille pääsyn tai poistumisen esteitä, potentiaaliset kilpailijat saapuvat markkinoille hyödyntääkseen näitä voittoja. Näin ollen erittäin keskittyneet markkinat eivät välttämättä merkitse normaalia parempia voittoja.

Vaikka kaupan vapauttaminen ja sääntelyn harmonisointi (EU, WTO) ovat madaltaneet markkinoillepääsyn ja markkinoilta poistumisen esteitä, silti eräitä suuria esteitä on jäljellä. Euroopassa esiintyy huomattavia eroavuuksia ruokakulttuurissa eri maissa ja alueilla. Vain muutamia elintarvikkeita myydään kaikkialla Euroopassa; useimmat elintarvikkeet on räätälöity paikallisten ruokatottumusten ja syömistapojen mukaisesti. Sen lisäksi on havaittavissa huomattavia eroavuuksia terveysvalvonnan ja ympäristösäännösten (mm. virvoitusjuomapullojen ja -tölkkien kierrätys) toteuttamisessa eri maiden välillä. Vaikka näiden säännösten tavoitteena on suojella kuluttajia, saattavat maiden väliset erot näissä säännöissä estää myös kauppaa ja kilpailua. Vähittäismyyntisektorilla puolestaan rajoitukset maankäytön suunnittelun säännöissä saattavat estää potentiaalisia kilpailijoita pääsemästä markkinoille.

\section{Kevytmaidon ja jauhelihan hintamarginaalien kehitys Suomessa (1975-2005)}

Kuvio 1 kuvaa elintarviketeollisuuden ja vähittäiskaupan prosentuaalisten hintamarginaalien kehitystä Suomessa 30 vuoden ajanjaksolla (1975- 2005) kahden hyödykkeen, kevytmaidon ja jauhelihan osalta. Hintamarginaaleja ovat laskeneet mm. Siren (1971), Haljala (1981), Laurinen (1996), Peltomäki (2000), sekä Mäkelä ja Niemi (2004).

Meijeriteollisuuden ja vähittäiskaupan prosentuaalinen hintamarginaali kevytmaidon vähittäishinnasta on vaihdellut 50 prosentin tietämillä läpi tutkimuskauden; nykyinen marginaali on lähellä keskiarvoa ja jää jälkeen 1980-luvun alun ennätystasosta. Teurastamoteollisuuden ja vähittäiskaupan prosentuaalinen osuus jauhelihan vähittäishinnasta on puolestaan noussut 1980-luvun alun noin 45 prosentista yli 60 prosenttiin 2000-luvun alussa. 
Mitkä tekijät sitten selittävät maidon ja jauhelihan erilaiset hintakehitykset? Ensiksikin, jalostuksen lisääntyneellä osuudella on ollut vain vähän vaikutusta näihin kahteen tuotteeseen, jotka ovat olleet koostumukseltaan tasalaatuisia läpi tutkimusajan. Maitotuotteiden hinnoittelussa on kuitenkin syytä epäillä ristiin subventoimista: täysmaidon (3,5 \% rasvaa) tuottajahintamarginaali on ollut suunnilleen 10 prosenttia korkeampi kuin kevytmaidon koko tutkimusjakson aikana. Meijerit ja vähittäiskauppa ovat todennäköisesti tasoittaneet eroja raaka-ainehinnoissa veloittamalla matalampaa marginaalia täysmaidolle, minkä seurauksena kevytmaidon ja täysmaidon kuluttajahinnat ovat olleet lähes identtiset läpi tutkimusajan.

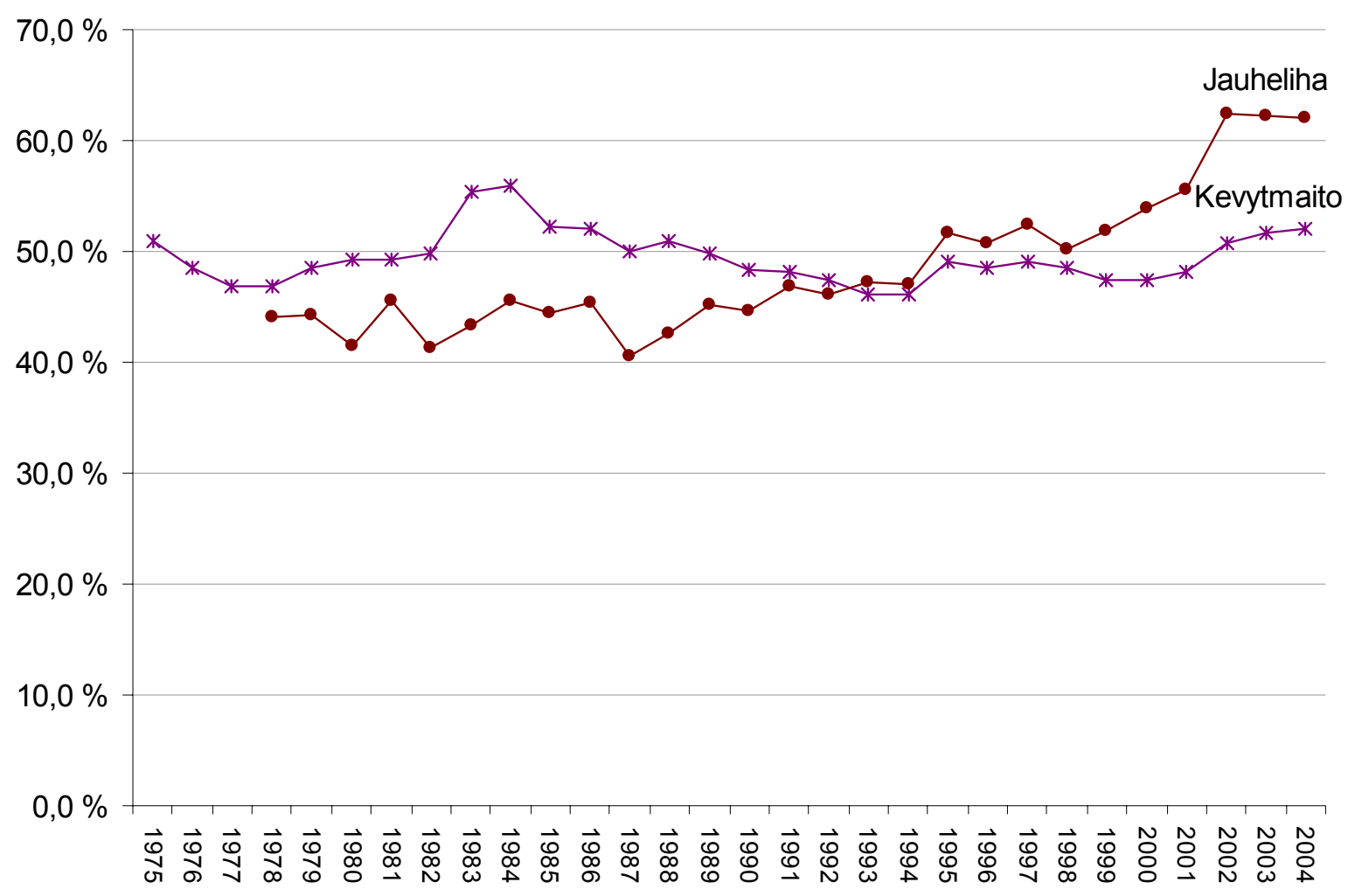

Kuvio 1: Elintarviketeollisuuden ja vähittäiskaupan hintamarginaalit (prosentteina kuluttajahinnasta) jauhelihassa ja kevytmaidossa vuosin 1975-2004.

Elintarvikehygienia on kohentunut selvästi 30 vuoden tarkastelukauden aikana. Omavalvonta tehtiin lakisääteiseksi kaikille elintarvikesektorin toimijoille vuoden 1995 lainsäädännössä. Vuodesta 2005 lähtien kaikilta elintarvikesektorin työntekijöiltä, jotka työskentelevät elintarvikeyrityksissä ja käsittelevät tuoreita ja pakkaamattomia elintarvikkeita, on vaadittu hygieniapassi. Hygieniapätevyys edellyttää jatkuvaa harjoittelua sekä tietojen päivittämistä, ja aiheuttaa näin ollen lisäkustannuksia elintarvikkeita jalostaville yrityksille. Elintarvikehygienian parannukset ovat kuitenkin tapahtuneet vaiheittain osana yritysten normaalia tuottavuuskehitystä, ja näiden parannusten kustannuksia on hyvin vaikeaa arvioida.

Tuottavuuden kasvulla on selvästi suuri merkitys pitkällä tähtäimellä elintarvikkeiden vähittäishintojen laskuun. Tuottavuuden kasvua tapahtuu läpi elintarvikeketjun, mutta toimialatason tuottavuustutkimukset (esim. Junka 2003) eivät anna tarpeeksi yksityiskohtaista kuvaa yksittäisen teollisuudenalan tuottavuuden kehityksestä. Esimerkiksi meijerisektorilla tuottavuus on saattanut kehittyä eri tahtia lihanjalostussektoriin verrattuna. Verrattaessa kaavion 3 hintasarjoja Junkan (2003) toimialatason tuottavuusarvioiden havaitaan kuitenkin eräitä mielenkiintoisia seikkoja. Meijerisektorilla hintamarginaalit ovat laskeneet sekä alkutuotannossa että teollisuus- ja vähittäiskaupassa ainoastaan noin 1-1.5 prosenttia vuodessa tutkimusjakson aikana, kun tuottavuuden kasvun arviot osoittavat 2,5-3 prosentin vuotuista TFP-kasvua. Koska meijeriyritysten kannattavuus ei ole parantunut, tuottavuuden kasvun on täytynyt olla hitaampaa meijerisektorilla kuin muissa elintarvikeketjun osissa. Kaaviosta 4 nähdään, että naudanlihan tuottajahinnat ovat pudonneet nopeammin eli 4-7 prosenttia vuodessa, mikä ylittää TFP-kasvuarviot koko maataloudessa. Sitä vastoin teollisuuden ja vähittäiskaupan hintamargi- 
naalien kasvu on ainoastaan 1-2 prosenttia, mikä on hieman vähäisempi kuin TFP-kasvu. Johtopäätöksenä voidaan todeta, että tuottavuuden kasvun erot elintarvikeketjun eri vaiheissa voivat selittää erilaiset trendit jauhelihamarginaaleissa, kun taas tuottavuuskasvulla ei ole huomattavaa vaikutusta kevytmaidon hintamarginaaleihin.

Suomen liittyminen EU:hun vuonna 1995 muutti maa- ja elintarviketalouden toimintaympäristöä hyvin radikaalisti. EU:hun liittymisellä näyttää kuitenkin olevan yllättävän vähän vaikutusta hintamarginaaleihin. Deflatoidut maidon tuottajahinnat ovat pysyneet pitkän aikavälin trendin mukaisena. Naudanlihan tuottajahinta putosi ensin selvästi alle pitkän aikavälin keskiarvon, mutta elpyi nopeasti takaisin pitkän aikavälin trendiin vuoteen 2001 mennessä.

Elintarviketeollisuuden ja vähittäiskaupan oligopolistista kilpailua syytetään usein tuottajahintojen laskusta. Suomalainen meijerisektori on ollut hyvin keskittynyt koko tutkimusajan: Valio hallitsee sektoria noin 80 prosentin markkinaosuudella, minkä jälkeen tulee Ingman (14\%) ja muut (6\%). Lihantuotanto on keskittynyt 1980-luvun lopusta lähtien, mutta markkinat ovat säilyneet kilpailullisempana kuin meijerisektorilla: tärkeimmät teurastamot vuonna 2006 olivat Atria (43\%), HK-Ruokatalo (36\%), Saarioinen (12\%), Snellmann (5\%) ja Karjaportti (4\%). Vähittäismyyntisektori on myös keskittynyt voimakkaasti läpi tutkimusajankohdan; viime vuosikymmenen aikana Kesko ja S-ryhmä ovat dominoineet markkinoita - kummallakin on lähes 35 prosentin markkinaosuus.

Jauhelihan hintamarginaalin nousua on kuitenkin vaikeaa selittää määräävän markkinavoiman väärinkäytöksi. Ensiksikin, jauhelihan toimittajia on enemmän kuin kevytmaidon toimittajia, minkä vuoksi lihateollisuuden hintakartellia on vaikeampi saavuttaa. Toiseksi, lihateollisuutta hallitsevat tuottajaosuuskunnat, joiden oletetaan maksimoivan yhteistuotot lihan alkutuotannosta ja jalostuksesta, ja joiden ei pitäisi harjoittaa aggressiivista hinnoittelua tuottajia kohtaan. Kolmanneksi, BSEepidemiasta johtuvan naudanlihan kysynnän laskun takia ei näytä todennäköiseltä, että vähittäiskauppa pystyisi lisäämään naudanlihan palkkioitaan enemmän kuin maitopalkkioitaan. Neljänneksi, lihantuotantoyritysten kannattavuus on ollut melko heikkoa viime vuosikymmenten aikana, ja monet tuottajaosuuskunnat ovat toimineet tappiollisesti. Tämä on ristiriidassa markkinavoimien väärinkäytöstä aiheutuneiden epänormaalien voittojen kanssa.

Kevytmaidon tuottajahintamarginaali ei ole juurikaan reagoinut jalostusasteen nousuun, maatalouspolitiikan muutoksiin, kansainvälisen kaupan tai epätäydellisen kilpailun tekijöihin. Havaitut muutokset hintamarginaaleissa voidaan selittää parantuneilla elintarvikehygienian vaatimuksilla ja tuottavuuden kasvulla. Viimeisen viiden vuoden aikainen maidon tuottajahintamarginaalin lasku on asetettava marginaalin 20-vuotisen tasaisen kasvun perspektiiviä vasten (vuodet 1980-2000). Naudanlihan tuottajahintamarginaali osoitti nopeampaa laskua ja jyrkempiä vaihteluita. Nämä selittyvät kaupankäynnin muutoksilla. Myös naudanlihan tapauksessa elintarvikehygienian kustannukset ja tuottavuuden kasvun muutokset osoittautuvat todennäköisimmiksi selityksiksi laskeviin tuottajaosuuksiin.

\section{Johtopäätökset}

Elintarvikkeiden kuluttajahintojen aleneviin tuottajahintamarginaaleihin on tarkasteltu kuutta erilaista selitystä. Analyysin mukaan tuottajahintamarginaalien yleiseen alenevaan trendiin on olemassa monia varteenotettavia syitä, mikä pitää tiedostaa hintamarginaaliarvioita tulkittaessa. Yleisesti ottaen eri vaikutustekijöiden eristäminen näyttää olevan hyvin hankalaa. Näiden mekanismien ymmärtäminen edellyttää saatavissa olevan empiirisen todistusaineiston huolellista analyysiä.

Kuuden vaikutustekijän todennäköisyyttä arvioitiin tulkittaessa kevytmaidon ja jauhelihan hintamarginaalien kehitystä suomalaisilla elintarvikemarkkinoilla vuosina 1975 - 2005 . Analyysissä korostui riittävän pitkän aikavälin tarkastelun tärkeys; viimeisten viiden vuoden aikana tuottajahintamarginaalin laskeva trendi ei näytä kovin hälyttävältä kun otetaan huomioon 20 vuoden edeltävä ajanjakso, jolloin hintamarginaali kasvoi tasaisesti. Empiirisen analyysin mukaan tuottavuuden kasvu ja parantuneen elintarvikehygienian kustannukset ovat ehkä tärkeimmät tekijät hintamarginaaleissa havaittuihin kehityslinjoihin. Kattavamman empiirisen todistusaineiston kokoamiseen tarvitaan kuitenkin lisää tutkimustyötä. 


\section{Kirjallisuus}

Allen, G. 1963. Evidence to the Committee of Enquiry into Fatstock and Carcase Meat Marketing and Distribution. Farm Economics, 10:153-184.

Baumol, W.J., J.C. Panzar, and R.D Willig 1982. Contestable Markets and the Theory of Industry Structure, Harcourt Brace Jovanovich, New York.

Digby, M. 1989. Marketing Margins in the Meat Sector, England and Wales 1978-198. Journal of Agricultural Economics 40:129-142.

Dobson, P., Waterson, M. \& Davies, S. 2003. The patterns and implications of increasing concentration in European food retailing. Journal of Agricultural Economics 54: 111- 125.

Gordon, R.J. 2004. Why Was Europe Left at the Station when America's Productivity Locomotive Departed?, NBER Working Paper 10661.

Haljala, H. 1981. Maataloustuotteiden kokonaismarginaalilaskelmat. Maatalouden taloudellisen tutkimuslaitoksen tiedonantoja 82: 37-49. Helsinki.

Junka, T. 2003. Maailman kilpailukykyisin maa? Tuottavuus ja investoinnit Suomessa 1975-2000, VATTResearch Reports 95, Helsinki.

Kinsey, J. and Senauer, B. 1996. Consumer Trends and Changing Food Retailing Formats. American Journal of Agricultural Economics 78:1187-1191.

Kjuus, J. 2004. Prisforsjeller i nordiske frukt- og grøntmarkeder [Marketing margins in nordic markets for fruit and vegetables]. Norwegian Agricultural Economics Research Institute, report 2004-8. 157 p.

Laurinen, H. 1996. Elintarvikkeiden hintamarginaalit vuosina 1985-1996. Maatalouden taloudellisen tutkimuslaitoksen tiedonantoja 214. Helsinki. 66 p.

Løyland, J., Pettersen, I., Selte, H., Becken, L-E. \& Flaten, O. 2001. Kjøttpriser fra bonde til butikk [Development of gross margins for pork and beef products from 1998 to 2001]. Norwegian Agricultural Economics Research Institute, report 2001-10. 52 p.

Mäkelä, S. \& Niemi, J. 2004. Elintarvikkeiden hintamarginaalit vuosina 2000-2002. MTT Taloustutkimus, käsikirjoitus. Helsinki. 9 p.

Niemi, J. \& Ahlstedt, J. (eds.). 2006. Finnish Agriculture and Rural Industries 2006. MTT Agrifood Research Finland, Economic Research, publications 106a. 96 p.

Niemi, J. \& Jansik, C. 2005. The behaviour of prices and marketing margins of selected food products in Finland. A paper presented at the NJF Seminar 381 "The Northern European Food Industry -challenges and transitions from an economic perspective", November 24-25, 2005, Helsinki, Finland.

O'Mahony, M., and B. van Ark 2003. EU Productivity and Competitiveness: Industry Perspective. Can Europe Resume the Catching-up Process? DG Enterprise, European Union, Luxembourg .

Peltomäki, M. 2000. Elintarvikkeiden hintamarginaalit vuosina 1997-1999. Maatalouden taloudellisen tutkimuslaitoksen selvityksiä 2/2000. Helsinki. 35 p.

Reed, A., Elitzak, H. and Wohlgenant, M. 2002. Retail-Farm Price Margins and Consumer Product Diversity. U.S. Department of Agriculture, Economic Research Service, Technical Bulletin No. 1899. 29 p.

Siren, J. 1971. Tärkeimpien maataloustuotteiden vähittäis- ja tuottajahintojen välisen marginaalin kehityksestä vuosina 1964-70. Maatalouden taloudellisen tutkimuslaitoksen tiedonantoja 16: 1-74. Helsinki.

Wohlgenant, M. 2001. Marketing margins: Empirical analysis. In: Gardner, B. and Rausser, G. (eds.). Handbook of Agricultural Economics, Volume 1 B, Amsterdam: North Holland, pp. 933-970. 